\title{
Microstructure and Dielectric Properties of $\mathrm{ZnO}-\mathrm{SiO}_{2}-\mathrm{NiO}$ Composite
}

\author{
Osama A. Desouky ${ }^{1}$, Mostafa M. H. Khalii ${ }^{2}$, Hamdy A. Kattab ${ }^{2}$ \\ ${ }^{1}$ Higher Institute of Engineering (BHIE), Bilbis, Sharqia, Egypt \\ ${ }^{2,3}$ Chemistry Department, Faculty of Science, Ain Shams University, 11566 Abbassia,Cairo, Egypt
}

\begin{abstract}
The effect of $\mathrm{SiO}_{2}$ addition on the properties of $\mathrm{ZnO}$-NiO composite were investigated. The samples with different SiO2 concentrations were fabricated by the conventional ceramic method and sintered at $1000^{\circ} \mathrm{C}$. The results of XRD show that Zn2SiO4 and $\mathrm{Ni}_{2} \mathrm{SiO}_{4}$ generate during sintering, The relative density for the samples increased as the NiO content increased; also it decreased as the $\mathrm{SiO}_{2}$ content increased. The presence of $0.1 \mathrm{wt} \% \mathrm{ZrO2}$ remained as chemically stable second phase particles among $\mathrm{ZnO}$ grains, and thus retarded densification and inhibited the grain growth of $\mathrm{ZnO}$ in the liquid phase sintering. The AC resistivity decreases with increasing frequency at room temperature.
\end{abstract}

Keywords: ceramics - $\mathrm{ZnO}-\mathrm{NiO}-\mathrm{SiO} 2$ - composite

\section{Introduction}

The study of composite materials, i.e., mixtures consisting of at least two phases of different chemical compositions, has been of great interest from both fundamental and practical standpoints. The macroscopic physical properties of such materials can be combined so as to produce materials with a desired average response [1]. Composites have good potential for various industrial fields because of their excellent properties such as high hardness, high melting point, low density, low coefficient of thermal expansion, high thermal conductivity, good chemical stability and improved mechanical properties such as higher specific strength, better wear resistance and specific modulus [2,3]. Composites are used in making solar cells, optoelectronic device elements, laser diodes and light emitting diodes (LED), industrial applications in aircraft, military and car industry. Besides this, the composites getting from the transition metal oxides are started to use as humidity and gas sensors [4]. $\mathrm{ZnO}$ oxide is a II-VI compound semiconductor with wurtzite structure [5]. $\mathrm{ZnO}$ films have been investigated as electronic and optoelectronic device materials such as, transparent conductors, solar cell windows, gas sensors and surface acoustic wave devices because of their n-type conducting with an optical transparency in the visible range. Various $\mathrm{ZnO}$ film preparation methods have been used; magnetron sputtering, spray pyrolysis, chemical vapor deposition (CVD), pulsed laser deposition and sol-gel process [6].

Zinc oxide $(\mathrm{ZnO})$ on the other hand is one of the versatile and technologically important semi conducting material because of its typical properties such as transparency in the visible range, high electrochemical stability, direct band gap (3.37) $\mathrm{eV}$, absence of toxicity, abundance in nature etc. [7]. $\mathrm{NiO}$ is a transition metal oxide that has several potential applications, such as solar thermal absorber, electrodes for battery and photoelectron-catalysts [6]. Nickel oxide (NiO) thin films are promising materials with excellent electrochromic properties . Other important application of Nickel oxide films includes preparation of alkaline batteries (as cathode material), antiferromagnetic layers and P-type transparent conducting films [8]. $\mathrm{NiO}$ is a p-type semiconductor with a band gap ranging from $3.6 \mathrm{eV}$ to $4.0 \mathrm{eV}$ transparent to ultraviolet (UV), visible and near infrared radiation .Silicon dioxide has been used as primary gate dielectric materials in field-effect device since the advent of first integrated circuit [9]. The other point of interest of silicon dioxide $\left(\mathrm{SiO}_{2}\right)$ compound in the industrial domain is due to its various qualities (electrical, optical, chemical and thermal properties). It is used widely in the optical and electronic applications (opto-electronic devices, optic fibers, etc). The crystal structure of silicon dioxide $\left(\mathrm{SiO}_{2}\right)$ has attracted the attention of many researchers because it is one of the most fundamental oxide systems [10]. It has low interfacial defect density, high melting point, large energy gap, high resistivity and good dielectric strength [11]. Nickel oxide $(\mathrm{NiO})$ and Zinc oxide $(\mathrm{ZnO})$ thin films have been prepared by various techniques, such as thermal evaporator, sputtering, sol-gel, spray pyrolysis, chemical vapour deposition and chemical bath deposition (CBD). For instance, work has been done on the microstructure, electrical and optical properties of $\mathrm{ZnO}-\mathrm{NiO}-\mathrm{SiO} 2$ nanocomposite synthesized by Sol-Gel Technique [12]. Other work carried out in this area includes synthesis and characterization of $\mathrm{ZnO}-\mathrm{NiO}$ composite nano particles by solution method etc [13]. Among all these different techniques for deposition, chemical bath deposition was successfully used to obtain $\mathrm{ZnO} / \mathrm{NiO}$ multilayer thin films due to its relative simplicity, low cost and potential application for large area deposition [14]. In this study, the polycrystal $\mathrm{ZnO}-\mathrm{NiO}-\mathrm{SiO}_{2}$ composite material was prepared by solid state method. The physical and electric and of the obtained composite materials were investigated.

\section{Material and Methods}

The powder was prepared using the mixed method in alcoholic medium . All the oxides used were analytical grade: $\mathrm{ZnO}, \mathrm{NiO}, \mathrm{SiO}_{2}$ and $\mathrm{ZrO}_{2}$. The weight compositions were shown in Table. 1 . The starting materials selected were $\mathrm{ZnO}$, $\mathrm{NiO}, \mathrm{SiO}_{2}$ and $\mathrm{ZrO}_{2}$ in powder form and all the materials were taken in the form of analytical grade. The prepared 


\section{International Journal of Science and Research (IJSR) \\ ISSN (Online): 2319-7064 \\ Index Copernicus Value (2013): 6.14 | Impact Factor (2014): 5.611}

$\mathrm{ZnO}, \mathrm{NiO}, \mathrm{SiO}_{2}$ and $\mathrm{ZrO}_{2}$ was wet ground in a ball for a period of 4 hours to pass 200 mesh sieves. The slurry was dried overnight. Batches were abbreviated as $\mathrm{S}_{1}, \mathrm{~S}_{2}, \mathrm{~S}_{3}, \mathrm{~S}_{4}$, $\mathrm{S}_{5}$, and $\mathrm{S}_{6}$ wet milled to ensure through mixing of the different compositions then dried at $110^{\circ} \mathrm{C}$. Two discs were used; the first one has $1.2 \mathrm{~cm}$ diameter and $0.2 \mathrm{~cm}$ thickness. These two discs were processed by a semi-dry press method under $70 \mathrm{KN}$. Small specimens were subjected to thermal treatment to select the proper maturing temperature for each mix. Three discs were always fired in muffle kiln with a rate of heating of $5{ }^{\circ} \mathrm{C} / \mathrm{min}$ in the temperature range between (1000 to1300 ${ }^{\circ} \mathrm{C}$ ) and for 2 hours. The sinterability of the different samples was determined in terms of physical properties. These sintered samples were used for morphological, structural and electrical characterizations. The XRD of different mixes were examined by using Philips apparatus type 170 , a vanadium $\left(\lambda=1.54 \mathrm{~A}^{\circ}\right)$ and Ni-filter in Metallurgy Research Center, Egypt. A continuous plot of intensity for $2 \theta$ values 4 to 80 was made at a scanning speed of $1 \%$ minute, with a paper speed of $10 \mathrm{~mm} / \mathrm{min}$. Both surfaces of the samples were lapped and ground with $\mathrm{SiC}$ paper and polished with $\mathrm{Al}_{2} \mathrm{O}_{3}$ powder to a mirror like surface. The polished samples were thermally etched at $900^{\circ} \mathrm{C}$ for $30 \mathrm{~min}$. The surface microstructure was examined by a scanning electron microscope (SEM, Joel- JEM. T 200). DTA locates the ranges corresponding to the thermal decomposition of different phases in paste, while TG measures the weight loss due to the decomposition. TG coupled with DTA makes it possible for the hydration reaction to be followed qualitatively, semi-qualitatively and quantitatively. Such thermal analysis is useful to observe the evolution of the hydration and especially to estimate the process of different reaction. Although these techniques are more suitable for studying hydration at later stages, they can be used as here, to consider the early phase of hydration accelerated by high temperature curing. Concerning DTA, $40 \mu \mathrm{m}$ powder specimens were placed in a refractory steel crucible and analyzed using a hybrid system with ovendrying at a heating rate of $5.8{ }^{\circ} \mathrm{C} / \mathrm{min}$ up to $95^{\circ} \mathrm{C}$. Sample masses ranged from 1.00 to $1.10 \mathrm{~g}$. In the case of $\mathrm{TG}$, the specimen (40 $\mu \mathrm{m}$ powder) was introduced into a quartz crucible and analyzed using system at a heating rate of $7.5^{\circ} \mathrm{C} / \mathrm{min}$ up to $600^{\circ} \mathrm{C}$. Masses of sample were between 200 and $220 \mathrm{mg}$. No trace of calcium carbonate was detected during analysis as the freeze-drying technique prevented carbonation of the sample hence thermo grams will be presented up to $600^{\circ} \mathrm{C}$ for DTA and $650^{\circ} \mathrm{C}$ for TG. The
PM 6304 program able automatic RCL meter was used for precise measurements of resistance, capacitance and inductance. From the measured values of capacitance, the dielectric constant at all frequency from $50 \mathrm{~Hz}-5 \mathrm{MHz}$ was calculated at constant temperature . The respective permittivity [ $\varepsilon-]$ was calculated according to the following relations: $\varepsilon^{\prime}=\frac{C d}{\varepsilon_{\sigma} A}$, Where $\mathrm{C}=$ capacitance in Farad., $\mathrm{d}=$ thickness of specimen in $\mathrm{m}$., $\varepsilon_{\mathrm{o}}=8.85 \times 10^{-12} \mathrm{~F} / \mathrm{m}, \mathrm{A}=$ area of specimen in $\mathrm{m}^{2}$. Also from the values of resistance $R$ conductivity $(\sigma)$ was calculated from the following relation: $\sigma=\frac{d}{R A}$, where $\mathrm{R}$ : resistance, $\mathrm{d}=$ thickness of specimen in $\mathrm{m}$ and $\mathrm{A}=$ area of specimen in $\mathrm{m}^{2}$.

Table 1: Composition of Different Mixes in $\mathrm{mol} \%$

\begin{tabular}{|c|c|c|c|c|}
\hline $\begin{array}{c}\text { Oxides/ } \\
\text { mixes }\end{array}$ & $\begin{array}{c}\mathrm{ZnO} \\
\text { mol\% }\end{array}$ & $\begin{array}{c}\mathrm{NiO} \\
\text { mole\% }\end{array}$ & $\begin{array}{c}\mathrm{SiO}_{2} \\
\text { mole\% }\end{array}$ & $\begin{array}{c}\mathrm{ZrO}_{2} \\
\text { mole\% }\end{array}$ \\
\hline $\mathbf{S}_{\mathbf{1}}$ & 40 & 55 & 5 & 0.1 \\
\hline $\mathbf{S}_{\mathbf{2}}$ & 30 & 60 & 10 & 0.1 \\
\hline $\mathbf{S}_{\mathbf{3}}$ & 40 & 40 & 20 & 0.1 \\
\hline $\mathbf{S}_{\mathbf{4}}$ & 40 & 35 & 25 & 0.1 \\
\hline $\mathbf{S}_{\mathbf{5}}$ & 40 & 30 & 30 & - \\
\hline $\mathbf{S}_{\mathbf{6}}$ & 30 & 30 & 40 & 0.1 \\
\hline
\end{tabular}

\section{Results and Discussion}

XRD patterns of samples sintered at $1000{ }^{\circ} \mathrm{C}$ are shown in Fig. 1. It is easy to identify the main phase $\mathrm{ZnO}, \mathrm{NiZnO}, \mathrm{NiO}$ , zinc silicate and nickel silicate by fitting $\mathrm{d}$ spacing data. The results show that $\mathrm{Zn} 2 \mathrm{SiO} 4$ and $\mathrm{Ni}_{2} \mathrm{SiO}_{4}$ generate during sintering, but the d-spacing data do not exactly match with those of JCPDS card. So a reaction may occur during furnace heating as follows:

$2 \mathrm{ZnO}+\mathrm{SiO}_{2}=\mathrm{Zn}_{2} \mathrm{SiO} 4$

$2 \mathrm{NiO}+\mathrm{SiO}_{2}=\mathrm{Ni}_{2} \mathrm{SiO} 4$

Then $\mathrm{Zn} 2 \mathrm{SiO} 4$ and $\mathrm{Ni}_{2} \mathrm{SiO}_{4}$ crystallized at the $\mathrm{ZnO}$ boundary during furnace cooling and formed potential barrier, and there is a little difference in d-spacing between $\mathrm{Zn}_{2} \mathrm{SiO}_{4}$ in the samples and JCPDS card. Therefore, the crystallized $\mathrm{Zn}_{2} \mathrm{SiO}_{4}$ is a solid solution dissolving and other elements. $\mathrm{SiO} 2$ does not react completely with others at $1000{ }^{0} \mathrm{C}$ because of the evidence of $\mathrm{SiO}_{2}$ existing in the sample sintering at 1000

${ }^{0} \mathrm{C}$ showed in the XRD patterns. 


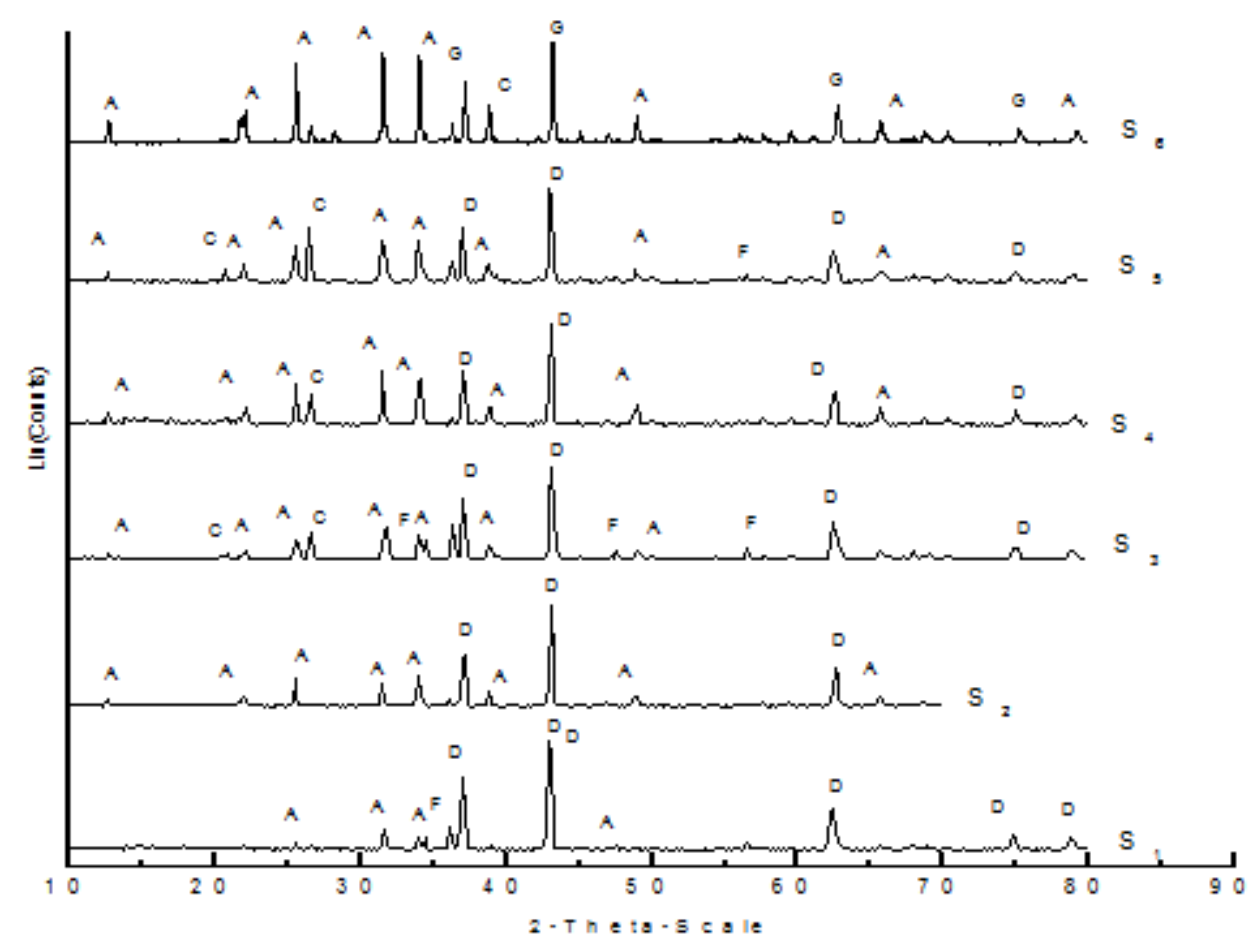

Figure 1: XRD patterns of different mixes

Where A: Zinc silicate $\mathrm{Zn}_{2}\left(\mathrm{SiO}_{4}\right)$, B: Nickel silicate, $\mathrm{Ni}_{2}\left(\mathrm{SiO}_{4}\right)$,

C: Quartz, D: Nickel Zink Oxide, F: Zink Oxide, G: Nickel Oxide.

The relative density for the fired samples in the temperature range between 1000 and $1300{ }^{\circ} \mathrm{C}$ is illustrated in Fig. 2. The relative density equals the theoretical density of a sample divided by its apparent density. The relative density for the samples increased as the $\mathrm{NiO}$ content increased; also it decreased as the $\mathrm{SiO}_{2}$ content increased. Although high densification rate in all samples took place at $1300{ }^{\circ} \mathrm{C}$, it is interesting that only samples $\mathrm{S}_{1}$ and $\mathrm{S}_{2}$ have better sintering behavior. At $1300{ }^{\circ} \mathrm{C}$, the relative density of samples $\mathrm{S}_{1}$ and $S_{2}$ have reached $95 \%$, which indicates that samples $S_{1}$ and $S_{2}$ get to almost full densification. Such a high rate of densification for sample S1 is thought to be attributed to the lowest glass transition temperature and the viscous glass phase during the firing process $[15,16]$. The highest densifications are obtained at high sintering temperatures and high sintering times., i.e the bulk density of $\mathrm{ZnO}-\mathrm{SiO} 2$ samples with $\mathrm{NiO}$ additions increases sharply with increasing temperature and has a constant value above $1000^{\circ} \mathrm{C}$.

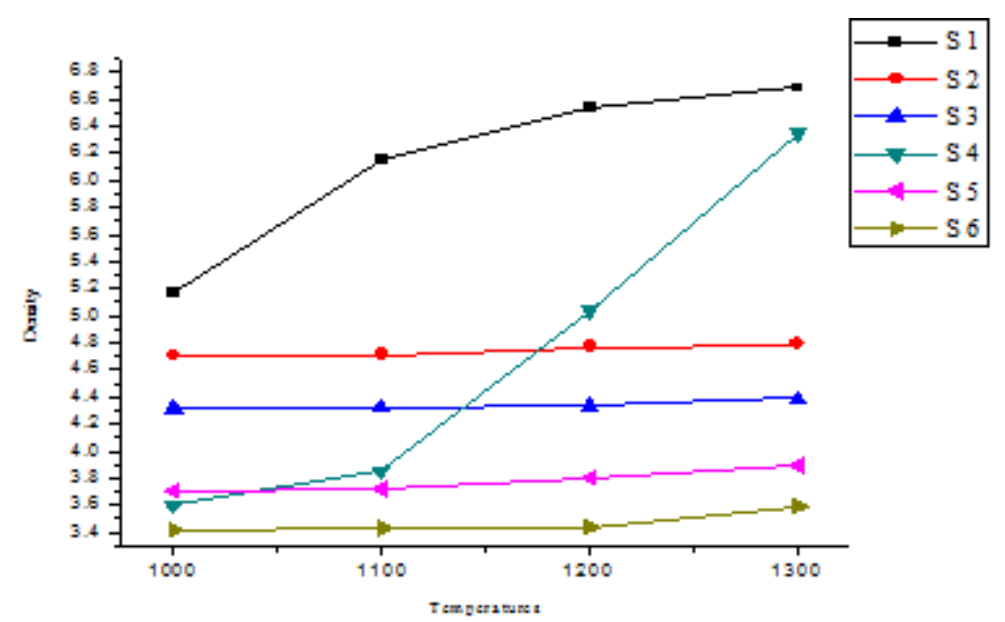

Figure 2: Relative density as a function of temperature

Fig. 3. shows the differential thermal analysis DTA thermo gram of sample [G(I)S2] which containing $40 \%$ wt $\mathrm{ZnO}$, $50 \%$ wt $\mathrm{NiO}, 10 \%$ wt $\mathrm{SiO} 2$ and $0.1 \%$ wt $\mathrm{ZrO} 2$. The thermo gram shows endothermic effect in which, the onset of the peak at $32.2^{\circ} \mathrm{C}$, the offset at $297.1^{\circ} \mathrm{C}$, the $\mathrm{mix} / \mathrm{min}$ at 104.1 ${ }^{\circ} \mathrm{C}$ is equal to $-16.436 \mu \mathrm{v}$, and heat change is equal to $1220.808 \mu \mathrm{Vs} / \mathrm{mg}$. 


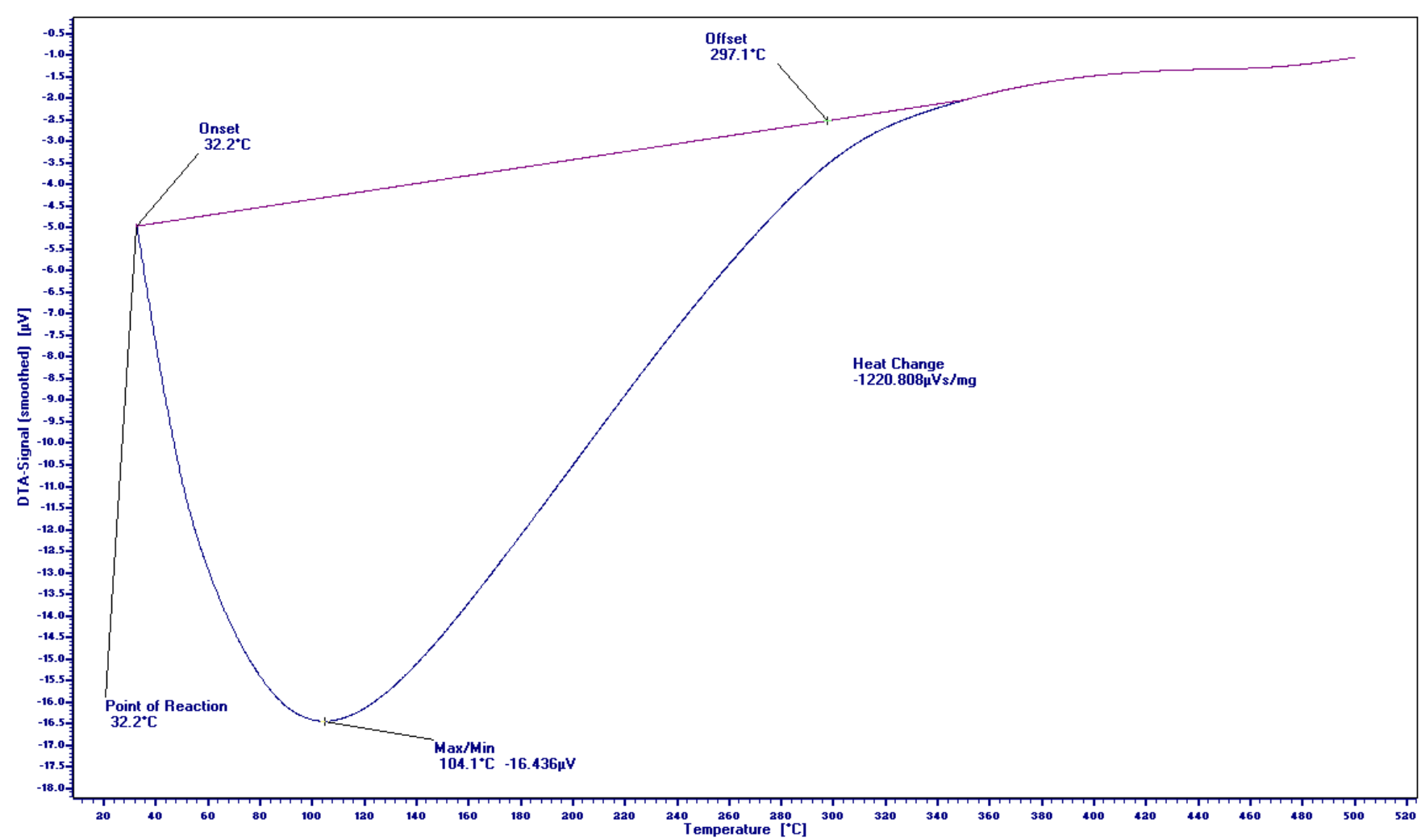

Figure 3: Show the DTA thermogram of sample S2

Fig.4. shows the TG thermo gram of sample $\mathrm{S}_{6}$, in which, mass of the sample at $56.3{ }^{\circ} \mathrm{C}$ is equal to $9.056 \mathrm{mg}$, mass of the sample at $207.5^{\circ} \mathrm{C}$ is equal to $8.493 \mathrm{mg}$, and mass change is equal to $-0.56 \mathrm{mg}$. In addition, mass of the sample at $207.5{ }^{\circ} \mathrm{C}$ is equal to $8.493 \mathrm{mg}$, mass of the sample at $268.9^{\circ} \mathrm{C}$ is equal to $7.975 \mathrm{mg}$, and mass change is equal to $0.52 \mathrm{mg}$. In addition, mass of the sample at $268.9^{\circ} \mathrm{C}$ is equal to $7.975 \mathrm{mg}$, mass of the sample at $344.2^{\circ} \mathrm{C}$ is equal to 7.758 $\mathrm{mg}$, and mass change is equal to $-0.22 \mathrm{mg}$.

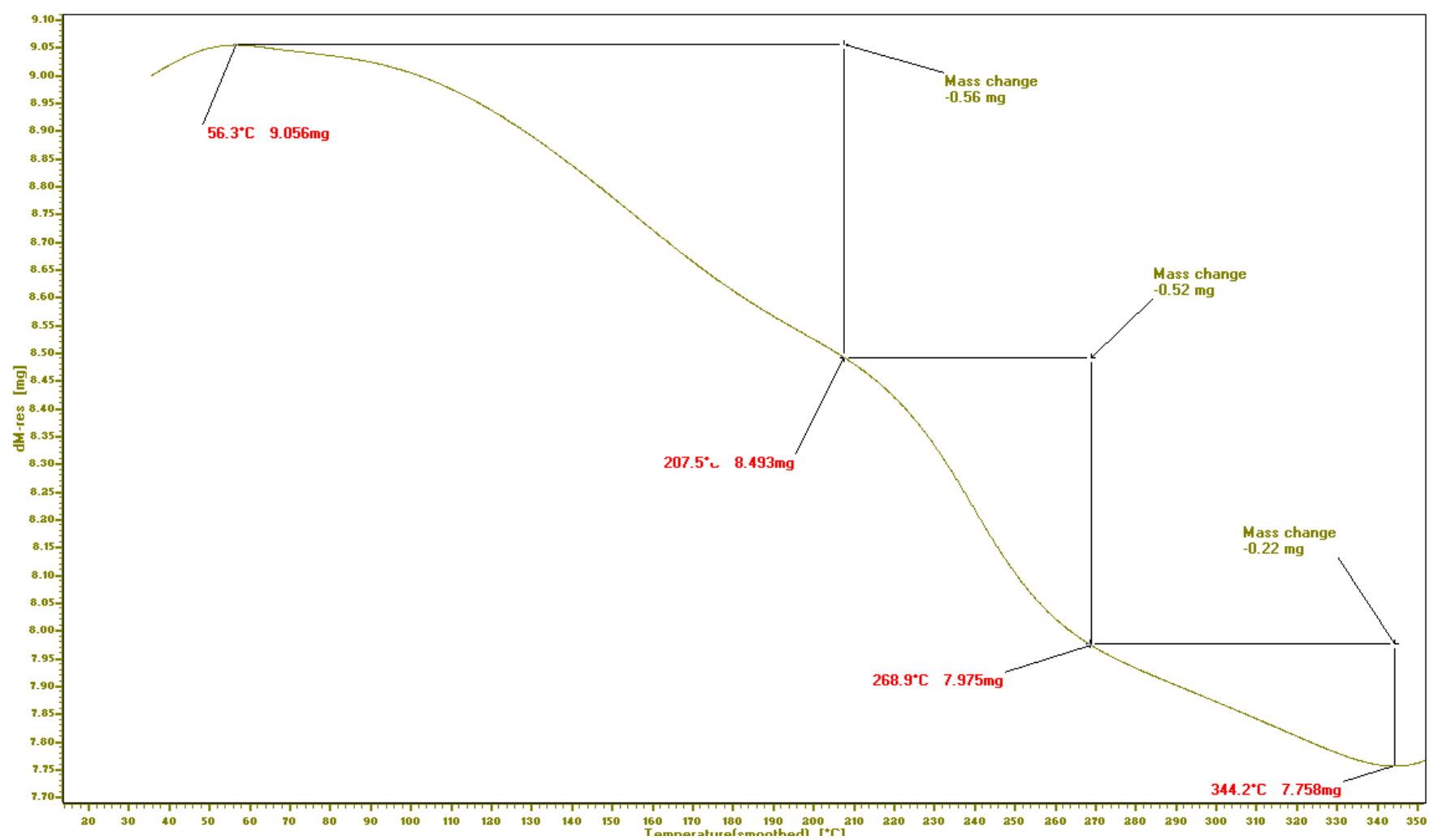

Figure 4: Shows the TG thermo gram of sample $\mathrm{S}_{6}$

The microstructure of $\mathrm{ZnO}-\mathrm{NiO}-\mathrm{SiO} 2$ sintered specimens' show uniformly sized grains of average size less than $10 \mathrm{pm}$.
Liquid phase sintering can produce smaller grains than that formed by solid state process. it can be concluded that the

\section{Volume 4 Issue 11, November 2015}




\section{International Journal of Science and Research (IJSR) \\ ISSN (Online): 2319-7064 \\ Index Copernicus Value (2013): 6.14 | Impact Factor (2014): 5.611}

effect of $\mathrm{NiO}$ addition was demonstrated not only by the decrease of the sintering temperature, but also by densification of $\mathrm{ZnO}-\mathrm{NiO}-\mathrm{SiO} 2$ ceramics. SEM of mix $\mathrm{S} 2$ is shown in Fig. 5 . There are different shades, the main bulk formed of grains of $\mathrm{ZnO}$ with smaller white nodal shaped grains, lying interagranulary .EDAX of these grains indicate that they are a mixture of $\mathrm{Ni}$ and $\mathrm{Zn}$. The decrease of grain

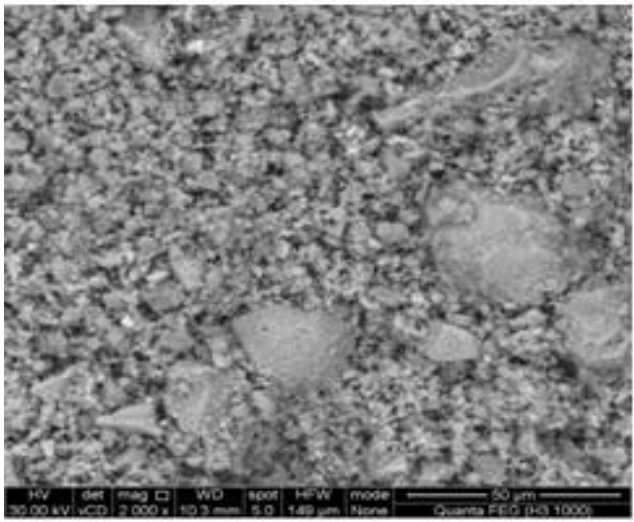

(a) size is attributed to the precipitation of secondary phase in the grain boundaries and nodal points. The presence of $0.1 \mathrm{wt} \%$ $\mathrm{ZrO} 2$ remained as chemically stable second phase particles among $\mathrm{ZnO}$ grains, and thus retarded densification and inhibited the grain growth of $\mathrm{ZnO}$ in the liquid phase sintering.

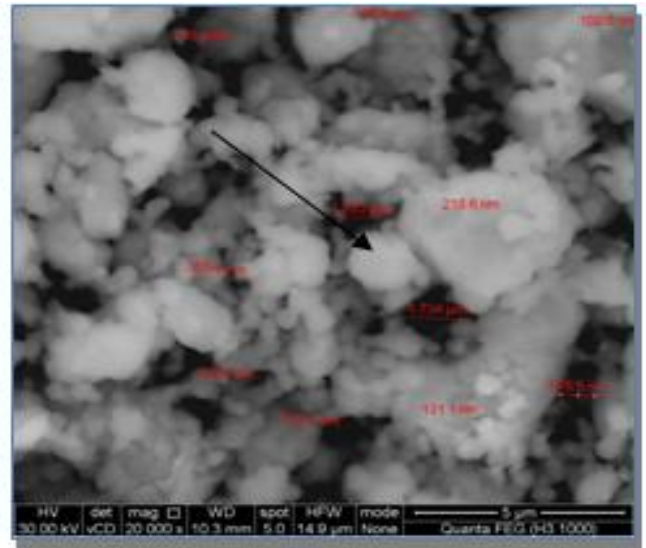

(b)

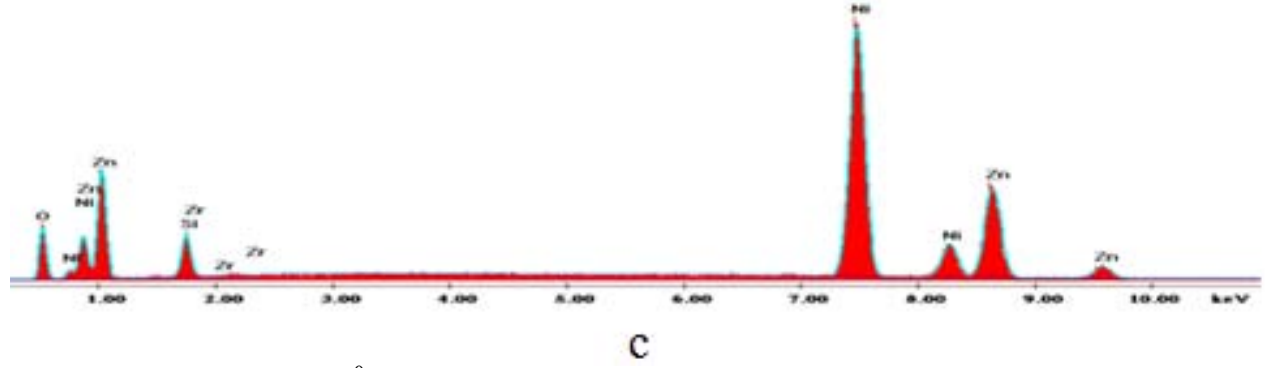

Figure 5: SEM of Mix $\mathrm{S}_{2}$ fired at $1000{ }^{\circ} \mathrm{C} / 2 \mathrm{~h}$. (a)Thermally etched , general view. $\mathrm{X}=2000$ (b)Thermally etched shows euhedral grains of $\mathrm{ZnO}$ randomly oriented. $\mathrm{X}=20000$ (c) EDAX of nodal shape in sample $\mathrm{S}_{2}$

Fig. 6. shows the microstructure of the as-prepared $\mathrm{ZnO}$ $\mathrm{NiO}-\mathrm{SiO} 2$ micro composite (mix S3). The $\mathrm{ZnO}$ grains are homogeneous, $\mathrm{NiO} \mathrm{SiO} 2$ particles are small and distributed at the boundary of the $\mathrm{ZnO}$ grains. Elementary composition analysis by EDAX confirms that the $\mathrm{Ni}$ and $\mathrm{Si}$ contents are higher near the grain boundary than in the matrix $(\mathrm{ZnO})$, indicating the formation of a $\mathrm{Ni}$ - rich phase along the $\mathrm{ZnO}$ grain boundaries.

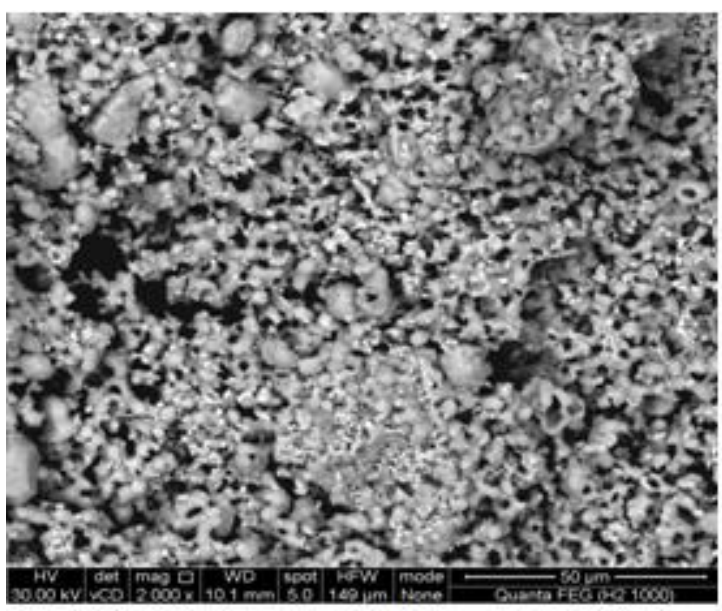

a

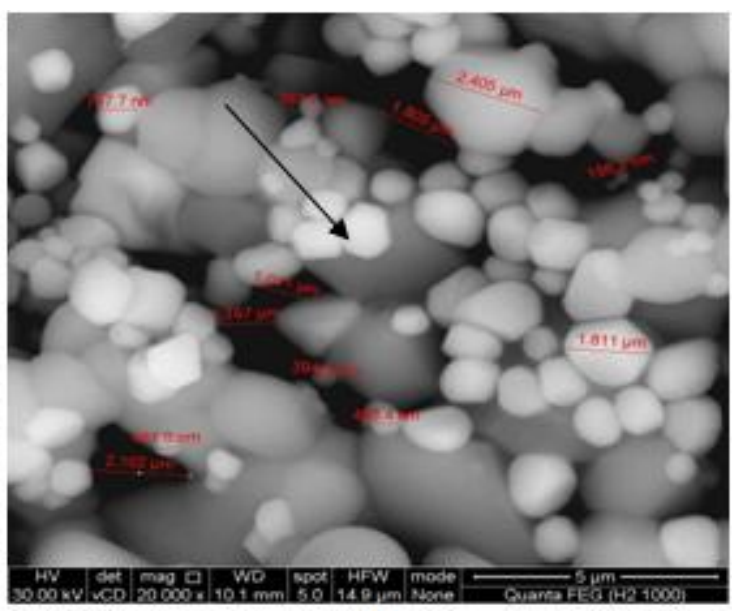

b 


\section{International Journal of Science and Research (IJSR) \\ ISSN (Online): 2319-7064}

Index Copernicus Value (2013): 6.14 | Impact Factor (2014): 5.611

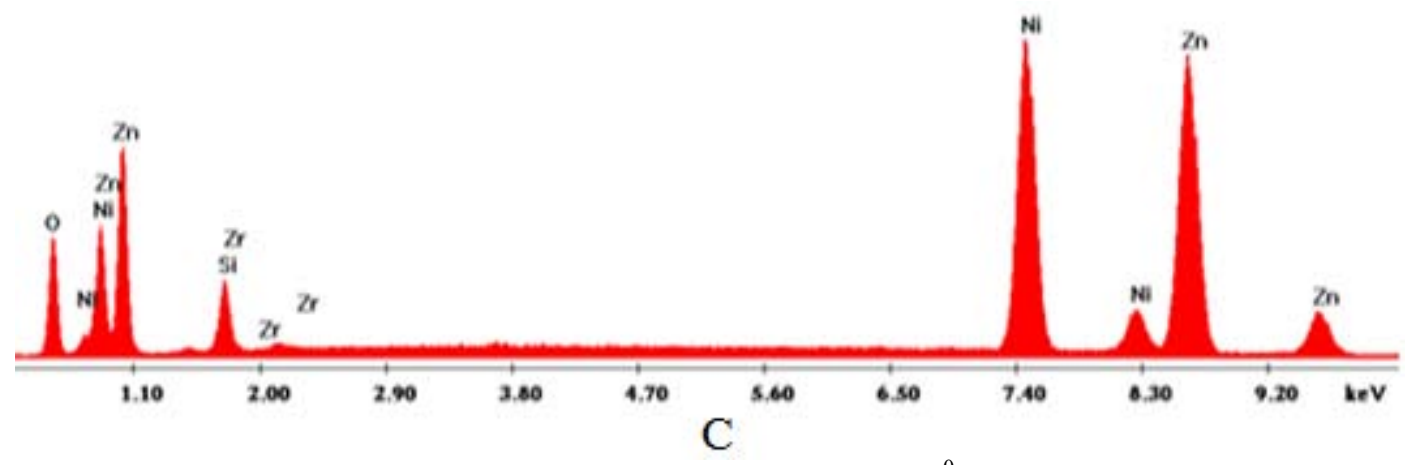

Figure 6: SEM of Mix S3 fired at $1000{ }^{0} \mathrm{C} / 2 \mathrm{~h}$

(a) Thermally etched, general view. $\mathrm{X}=2000$

(b) Thermally etched shows oval shape of $\mathrm{Ni}$ - rich phase between grains of $\mathrm{ZnO} . \mathrm{X}=20000$ (c) EDAX of oval shape in sample $\mathrm{S}_{3}$

Fig. 7. SEM of sample $\mathrm{S}_{5}$, shows the segregation of the intergranular phase in patches. This is evident from the different shades displayed varying from dark grey - light grey and white. The samples were of very dense microstructure. Although some pores were present, they were very small and separated from one another. The decrease of grain size is attributed to the precipitation of secondary phase in the grain boundaries and nodal points.

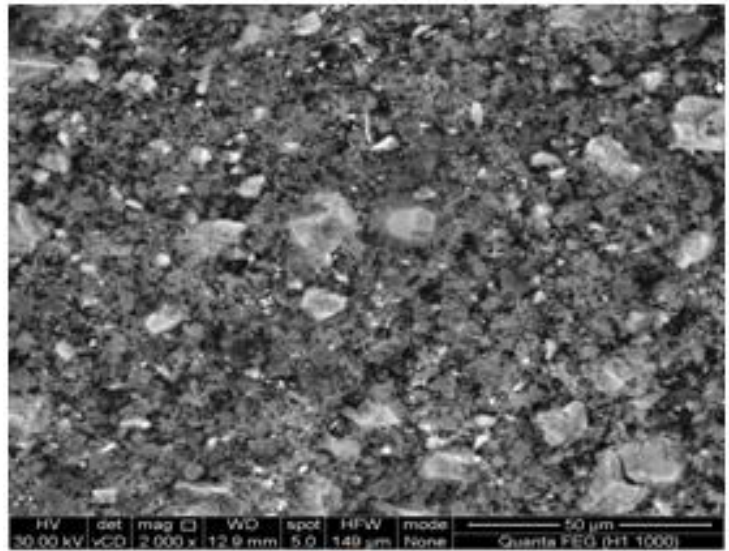

a

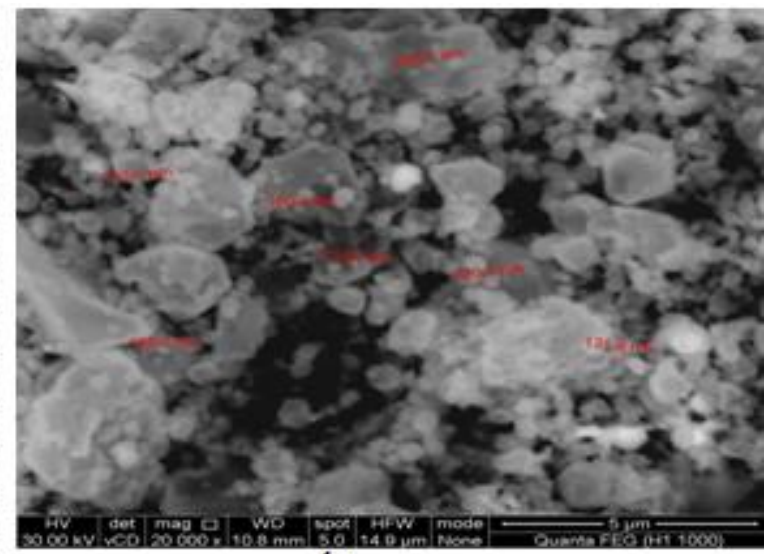

b

Figure 7: SEM of Mix S5 fired at $1000{ }^{0} \mathrm{C} / 2 \mathrm{~h}$.

(a)Thermally etched, general view. $\mathrm{X}=2000$

(b) Thermally etched shows intergranular phase, light in color. $X=20000$

Fig. 8. Shows the variation of the dielectric constant as a function of frequency for all samples. Obviously, the dielectric constant shows a decreasing trend for all the samples. The decrease is rapid at lower frequency and slower and stable at higher frequency. The decrease of dielectric constant with increasing frequency is a normal dielectric behavior which is also observed by other researchers [17-19]. A composite ceramic system is considered as heterogeneous material that can experience interfacial polarization as predicted by Maxwell and Wagner. They pointed out that at low frequency region (refer to Figure 8) the movement of charge carriers trapped at interfacial region which is caused by inhomogeneous dielectric structure. At high frequency, the dominant mechanism contributing to dielectric constant is the hopping mechanism in their respective interstice under the influence of alternating current. The frequency of hopping between ions could not follow the frequency of applied field and hence it lags behind, therefore the values of dielectric constant become reduced at higher frequency [20].
A low loss factor is desirable for a dielectric material so that the dissipated electric power to the insulator is minimized. This type of consideration is very important for high power circuits operating at high speed. Dissipation factor is a ratio of the energy dissipated to the energy stored in the dielectric material. The more energy that is dissipated into the material, the less is going to make it to the final destination. This dissipated energy typically turns into heat or is radiated as radio frequency (RF) into the air. The optimal goal is to have $100 \%$ of the signal pass through the interconnection network and not be absorbed in the dielectric. A high loss material means a little or no signal is left at the end of the transmission path. In other to retain maximum signal power, a low loss material should be used. The defect, space charge formation and lattice distortion is believed to produce an absorption current resulting in a loss factor and at high alternating frequency those could follow the field applied and later values the trend saturated [20].

As can be seen in Fig . 8 ,, the $\varepsilon^{-}$value is reduced with increase in $\mathrm{NiO}$ wt. \% and it start to be constant at frequency $1 \mathrm{MHz}$. The reduction in the $\varepsilon^{-}$values is due to the structure 


\section{International Journal of Science and Research (IJSR) \\ ISSN (Online): 2319-7064 \\ Index Copernicus Value (2013): 6.14 | Impact Factor (2014): 5.611}

of the prepared sample. The low dielectric constant can be produce by having a porous structure. The graphs of dielectric constant with frequency are shown in Fig .6. From these figure, it can be seen that the dielectric constant initially decreases rapidly with increase in applied frequency up to a certain frequency $1 \mathrm{kHz}$ and beyond that remains fairly constant for all the compositions. The decrease in dielectric with increase in applied frequency is also reported for $\mathrm{Cu}-\mathrm{Zn}$ ferrites [21-22]. This behavior may be due to existence of interfacial polarization [23]. Dielectric properties are mainly governed by the conduction mechanism in $\mathrm{ZnO}-\mathrm{NiO}-\mathrm{SiO} 2$ micro and nanocomposite, where in electron hopping takes place. This electron hopping looks to be favorable at lower applied electric field frequencies. Therefore, at lower frequency the dielectric constant is maximum. The dielectric behavior for the present samples can be explained on the basis that the mechanism of polarization process in ferrites is similar to that of conduction process.

In normal dielectric behavior, the dielectric constant decreases with the increasing frequency reaching a constant value. Dielectric thicknesses are the important parameters that will influence capacitor performance. Since the capacitance is porosity dependence and from the formula, capacitance is directly proportional to the dielectric constant of the material, hence the reduction in the dielectric constant value also due to the porosity produced in the specimens as shown in Figs (5-8). It is seen that the dielectric constant of the composites gradually decreases with increase in $\mathrm{SiO}_{2}$ filler content. It is a well-known fact that the dielectric constant of $\mathrm{SiO}_{2}$ filler is 3.8 Thus; the resultant dielectric constant of combined $\mathrm{ZnO}-\mathrm{NiO}-\mathrm{SiO} 2$ micro composite gradually decreases with increasing $\mathrm{SiO}_{2}$. The highest value of permittivity at $1 \mathrm{kHz}$ at room temperature, and an evident dependence of frequency is recorded for $30 \% \mathrm{NiO}$ addition to $\mathrm{ZnO}+\mathrm{SiO} 2$ composite ceramics sintered at $1000^{\circ} \mathrm{C}$ which is characterized by a uniform microstructure and highest density .i.e. The variation in dielectric permittivity behavior hardly can be related only to the differences in microstructure, since the grain sizes are similar in most of the specimens. The relation between resistivity and frequency for different mixes are shown Fig. 9. This figure shows that the AC resistivity decreases with increasing frequency at room temperature. This may be attributed to the increase in the number of dipoles and consequently increases the hopping probability. Also the increase of frequency decreased the resistivity because it increases the ionic response to the field variation.

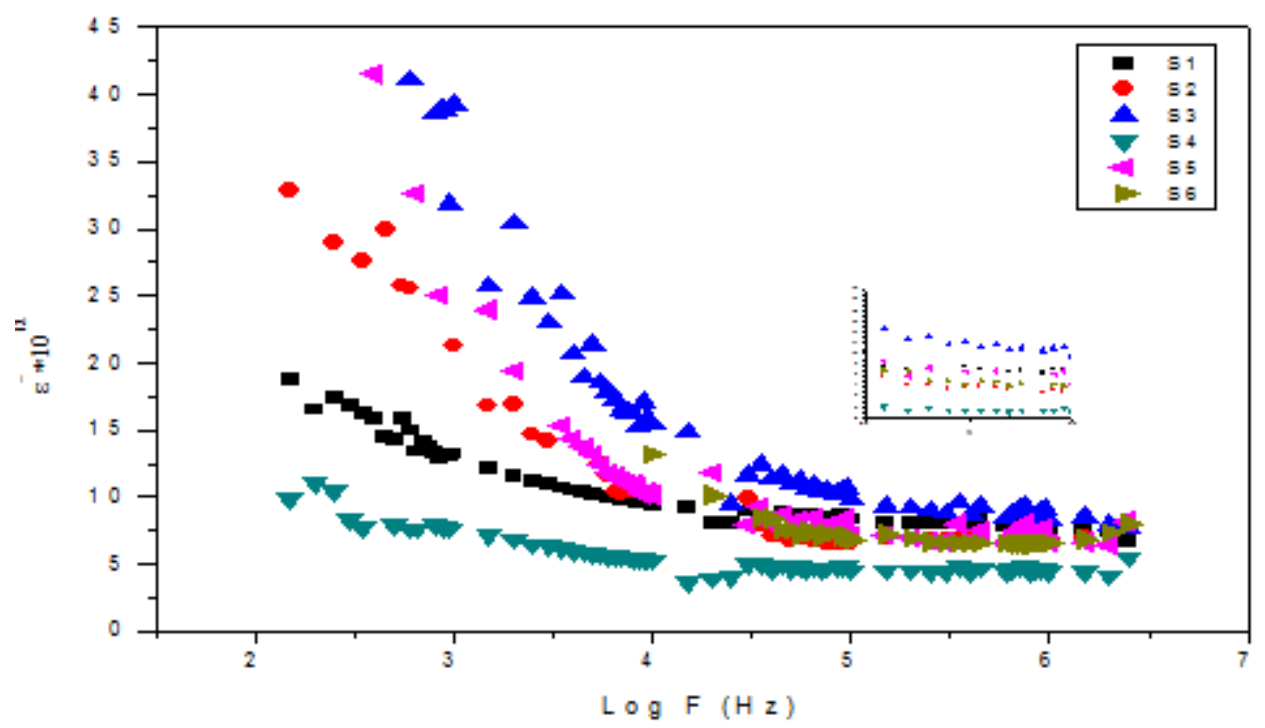

Figure 8: The frequency dependence of the dielectric constant 


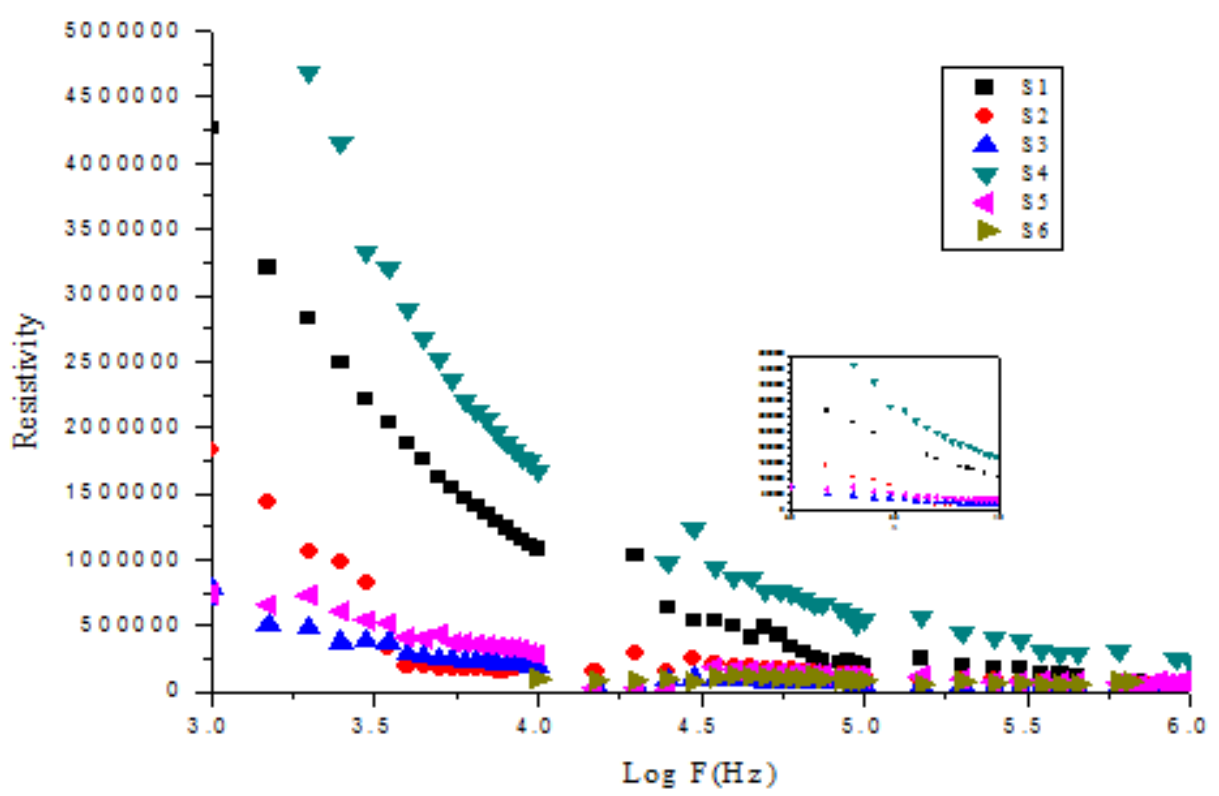

Figure 9: AC resistivity as a function of frequency at room temperature of different mixes

\section{Conclusions}

1) Addition of $\mathrm{SiO}_{2}$ in the presence of $\mathrm{ZnO}$ and $\mathrm{NiO}$ leads to better densification by minimizing the present of closed pores. Results of firing shrinkage as a function of temperature show increase of shrinkage with temperature.

2) The relative density for the samples increased as the $\mathrm{NiO}$ content increased; also it decreased as the $\mathrm{SiO}_{2}$ content increased.

3) The dielectric constant shows a decreasing trend for all the samples, the decrease is rapid at lower frequency and slower and stable at higher frequency.

4) The AC resistivity decreases with increasing frequency at room temperature. This may be attributed to the increase in the number of dipoles and consequently increases the hopping probability.

\section{References}

[1] M.Peko Jean-Claude, L .Deusdedit. JR .Spavieri., L. Charles. Da Silva, Carlos A. Fortulan, Dulcina P.F. de Souza, Milton F. De Souza, Solid State Ionics, 156 (2003) 59.

[2] Y.Sahin, Kompozit Malzemelere Giriş, Gazi Üniversitesi, (2000).

[3] K.M. Shu, G. C. Tu,. Materials Science and Engineering (2002) 236.

[4] C. Aksu CanbayMaster Thesis, Frrat University , Graduate School of Natural and Applied Sciences, Elazıg-TURKEY, (2005).

[5] J.Lu, Z.Ye, L. Wang, J. Huang, B.Zhao, Materials Science in Semiconductor Processing, 5, (2003) 491.

[6] Y. Natsume, Sakata, H. Materials Chemistry and Physics, 9594 (2002) 1.

[7] S.V. Han, D.H. Lee, V.J. Chang, S.O. Ryu, T.J. Lee, C.H. Chang. Journal of the Electrochemical Society, 153(6), (2006) 382.

[8] V.R. Shinde, C.D. Lokhande, R.S. Mane, H. SungHwan, Applied Surface Science, 245, (2005) 407
[9] B.N. Wang, O.Y. Li, Z.R. Nie, Z.H. Wang, Q. Wei, Journal of Colloid and Interface Science, 320, (2005) 254.

[10] Q.Li, S.J. Wang, P.C. Lim, J.W. Chai, A.C.H. Huan, C.K. Thin Solid Films 462 (2004) 106.

[11]W. Bekhti, M. Ghamnia, Catalysis Today, 89, (2004) 303.

[12]N. Rana, P. Raghu, E. Shero, F.Shadman, Applied Surface Science, 205 (2003)160.

[13] A.C. Canan, A. Ayse, Turkish Journal of Science and Technology, 4(2), (2009)121.

[14] V. Mohammad, Theories and Applications of Chemical Eng., 14(2) (2008)

[15] M.A. Vidales-Hurtado, A. Mendoza-Galvan, Materials Chemical and Physics, 107(2008) 33.

[16] G.H. Chen, X.Y. Liu, J. Mater. Sci.: Mater. Electron. 15 (9) (2004) 595.

[17] H. Chenari. Mahmoudi, Ali Hassanzadeh, *, M.M. Golzan, H. Sedghi, M. Talebian ,Current Applied Physics 11 (2011) 409.

[18] B. H. Venkataraman, K.B.R. Varma, Solid State Ionics 167 (2004) 197

[19] D. Ravinder, G. Ranga Mohan, Prankishan, Nitendarkishan, D.R. Sagar, Materials Letters 44 (2000) 256.

[20] Kumar, G. B. and Buddhudu, S. Ceram. Int. 36, (2010)1857.

[21] S.G. Kulkarni, Ph.D. Thesis, Shivaji University, Kolhapur, 1995. [21] A.Y. Lipare, Ph.D. Thesis, Shivaji University, Kolhapur, 2002.

[22] A.Y. Lipare, P.N. Vasambekar, A.S. Vaingankar, Mater. Chem. Phys. 81 (2003) 108.

[23] M.A. Abdullah, A.N. Yusoff, J. Alloys Compounds 233 (1996) 129. 